\title{
Detection of diploid males in a natural colony of the cleptobiotic bee Lestrimelitta sp (Hymenoptera, Apidae)
}

\author{
Mara Garcia Tavares ${ }^{1}$, Carlos Roberto Carvalho $^{1}$, Fernanda Aparecida Ferrari Soares ${ }^{1}$ \\ and Anderson Fernandes ${ }^{1,2}$ \\ ${ }^{1}$ Departamento de Biologia Geral, Universidade Federal de Viçosa, Viçosa, MG, Brazil. \\ ${ }^{2}$ Departamento de Ciências Biológicas, Universidade do Estado de Mato Grosso, Mato Grosso, MT, Brazil.
}

\begin{abstract}
When working at quantifying the genome size of stingless bees, it was observed that males of Lestrimelitta sp possessed the same amount of nuclear DNA as the females. Thus, we used flow cytometry (FCM) and cytogenetic analysis to confirm the ploidy of these individuals. The males analyzed proved to be diploid, since, through cytometric analysis, it was demonstrated that the mean genome size of both males and females was the same $(C=0.463 \mathrm{pg})$, and, furthermore, cytogenetic analysis demonstrated that both had $2 n=28$ chromosomes.
\end{abstract}

Key words: cytogenetic, flow cytometry, genome size, karyotype, stingless bee.

Received: November 11, 2009; Accepted: March 30, 2010.

In Hymenoptera, sex is determined by haplodiploidy and in several species it is regulated by a single, multiallelic sex locus (sl-CSD) (Beye et al., 2003). In this model, hemizygous individuals will become males (haploid drones), whereas diploid individuals that are heterozygous at the sex locus will develop into females and those homozygous into diploid males.

In general, diploid males are less viable (Whiting, 1943; Rothenbuhler et al., 1968), and either sterile (El Agoze et al., 1994; Duchateau and Marien, 1995; Krieger et al., 1999) or produce diploid sperm which leads to triploid offspring (Naito and Susuki, 1991; Liebert et al., 2005; de Boer et al., 2007), thereby imposing a genetic load on the population as a whole. In only one of the species studied so far, Euodynerus foraminatus, fertility is normal in diploid males, with the production of diploid, rather than triploid female offspring (Cowan and Stahlhut, 2004).

Diploid males have been detected in more than 60 species of Hymenoptera, this including several species of bees (both social and solitary), wasps, ants, sawflies and parasitoids. Among the stingless bees, they have been observed only in Melipona compressipes, M. quadrifasciata, Scaptotrigona postica, Trigona carbonaria and Tetragona quadrangula (van Wilgenburg et al., 2006, Heimpel and de Boer, 2008), but not so in the genus Lestrimelitta.

Lestrimelitta is an essentially cleptobiotic (robber) stingless bee that exploits the resources of other bees by stealing food from their nests, instead of collecting it from

Send correspondence to Mara Garcia Tavares. Departamento de Biologia Geral, Universidade Federal de Viçosa, Av. P H Rolfs s/n, Campus Universitário, 36570-000, Viçosa, MG, Brazil. E-mail: mtavares@ufv.br. flowers (Sakagami and Laroca, 1963; Bego et al., 1991; Sakagami et al., 1993). The genus occurs in the Neotropical region (Michener, 2000), and is represented in Brazil by at least fourteen species (Marchi and Melo, 2006).

When dealing with the quantification of genome size in stingless bees, it was noted that, in a colony of Lestrimelitta sp obtained in Domingos Martins/Espírito Santo $\left(20^{\circ} 21^{\prime} 48^{\prime \prime} \mathrm{S}\right.$; 40³9'33" W), nuclear DNA content proved to be the same in both males and females. As diploid males had not been previously noted in this species, individual ploidy was thereupon confirmed by flow cytometry (FCM) and cytogenetic analysis.

For the FCM analysis, the nuclear DNA content of Lestrimelitta sp male and female larvae was measured by using the C DNA content $(0.42 \mathrm{pg})$ of Scaptotrigona xantotricha as internal standard, as described by Lopes et al. (2009). Brain ganglion nuclei of the standard and sample were excised in physiological saline solution $(0.155 \mathrm{mM} \mathrm{NaCl})$. The material was simultaneously crushed 10 times with a pestle in a tissue grinder (Kontes Glass Company $^{\circledR}$ ) with $100 \mu \mathrm{L}$ of OTTO-I lysis buffer (Otto, 1990) containing $0.1 \mathrm{M}$ citric acid (Merck), 0.5\% Tween 20 (Merck) and $50 \mu \mathrm{g} \mathrm{mL}^{-1}$ of RNAse (SigmaAldrich), $\mathrm{pH} 2.3$. The suspension was adjusted to $1.0 \mathrm{~mL}$ with the same buffer, filtered through a $30 \mu$ mylon mesh (Partec) and centrifuged at $100 \mathrm{~g}$ in microcentrifuge tubes for $5 \mathrm{~min}$.

The pellet was then incubated for $10 \mathrm{~min}$ in $100 \mu \mathrm{L}$ of OTTO-I lysis buffer, and stained with $1.5 \mathrm{~mL}$ of OTTOI:OTTO-II (1:2) solution (30 $\mathrm{min})$ (Loureiro et al., 2006), supplemented with $75 \mu \mathrm{M}$ of propidium iodide (PI) and 
$50 \mu \mathrm{g} \mathrm{mL} \mathrm{m}^{-1}$ of RNAse, $\mathrm{pH}=7.8$. The nuclear suspension was filtered through a $20 \mu \mathrm{m}$ diameter mesh nylon filter and maintained in the dark for 5-40 min.

Three independent replicates of each suspension were analyzed with a Partec PAS flow cytometer (Partec) equipped with a Laser source $(488 \mathrm{~nm})$.

The mean genome size (pg) of each bee sample was measured according to a formula adapted from Dolezel and Bartos (2005).

For cytogenetic analysis, metaphase chromosomes were obtained from cerebral ganglia and testes of male larvae, and from cerebral ganglia of females in the final defecation stage (Imai et al., 1988). On an average, 5 females and 15 males, with ten metaphases per individual, were analyzed. Conventional Giemsa staining, using a $0.06 \mathrm{M}$ Sörensen buffer, $\mathrm{pH}$ 6.8, was carried out according to Rocha and Pompolo (1998).

A 12-bit CoolSNAP-Pro cf (Roper Scientific) video camera, assembled on an OlympusTM BX-60 microscope with a 100x objective, was used for capturing chromosome images. The frame was digitized using an Image Pro-Plus analysis system (Media Cybernetics). A Power Macintosh G4 computer was employed for image analysis, with freely available Image SXM software (Barrett, 2002). This is a spin-off of the public domain image analysis application NIH Image which was developed by Rasband (1998). The karyotype was mounted by pairing chromosomes in the order of decreasing size.

Cytometry analysis of nuclei suspensions stained with PI demonstrated that the mean genome size of both males and females was the same $(\mathrm{C}=0.463 \mathrm{pg}$ ) (Table 1 and Figures 1a and 1c), thereby indicating that the males were diploid.

Cytological analysis confirmed female and male chromosome content to be $2 \mathrm{n}=28$ (Figures $1 \mathrm{~b}$ and $1 \mathrm{~d}$ ), as already described for Lestrimelitta limao females (Rocha et $a l ., 2003)$. Neither cytometry nor cytogenetic analysis revealed haploid males among those analyzed.

The presence of diploid males is likely to generate high fitness costs for individual colonies and their queens, since there is a potential reduction in the proportion of workers performing essential tasks for colony survival (Green and Oldroyd, 2002). In colonies of stingless bees, workers construct and mass provision the cells prior to ovipositing. Thereafter, the queen lays her eggs in the cells, which the workers then seal (Sakagami, 1982). This pre-
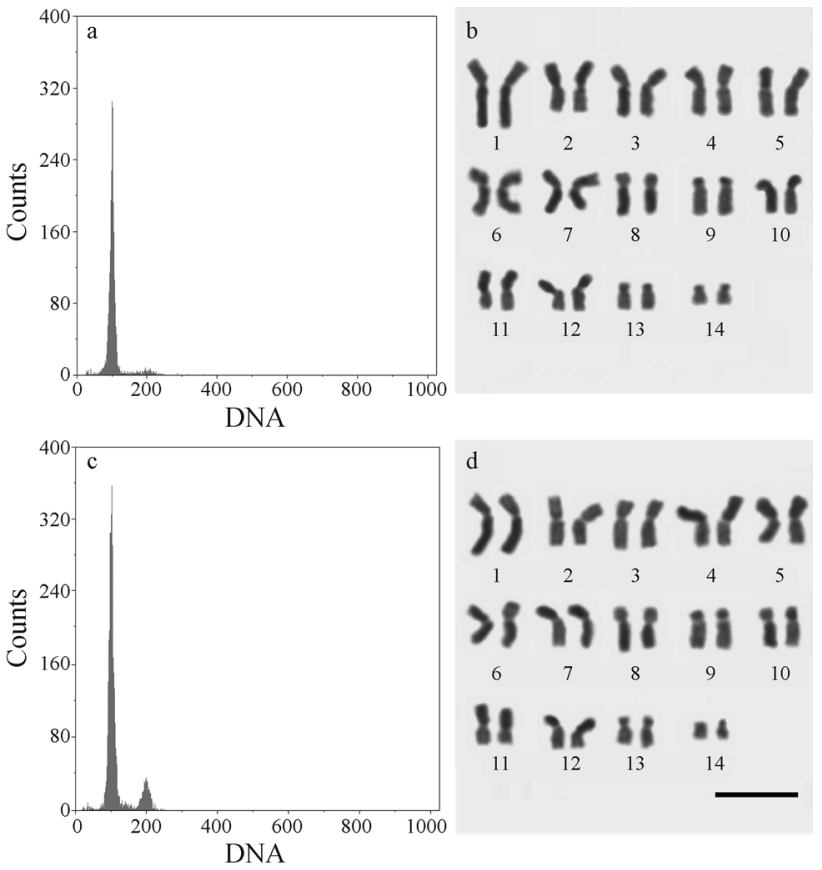

Figure 1 - Genome size DNA-histograms and karyotype (Giemsa staining) of female (a and b) and diploid male (c and d) of Lestrimelitta sp. $\mathrm{Bar}=5 \mu \mathrm{m}$.

vents the detection and early removal of diploid males. In fact, it was noted that diploid males of Lestrimelitta sp presented normal viability in the larval and pupa phases, and fully developed into imagos. Nevertheless, several workers were seen attacking young diploid males inside the colony. Furthermore, the colony was weak, presenting several brood cells with dead progeny, with numerous mites attacking the larvae. This colony perished only a few days after being opened in the laboratory. Likewise, in colonies of Bombus atratus (Plowright and Pallet, 1979) and Solenopsis invicta (Ross and Fletcher, 1986), the production of diploid males also retarded colony growth, with consequential high mortality.

Diploid male production has been attributed to habitat fragmentation, the loss of sex allele diversity by drift in small, isolated populations, and the mating of parents sharing a sex allele in common, i.e., matched matings (revision in Cowan and Stahlhut, 2004). For Lestrimelitta in particular, the active human destruction of its colonies, in order to countering pillage of other stingless bee colonies, could have reduced species population size, thus favoring in-

Table 1 - Estimation of genome size of cerebral ganglia of Lestrimelitta sp.

\begin{tabular}{lcccc}
\hline & \multicolumn{4}{c}{ Mean genome size (1C; pg) } \\
\cline { 2 - 5 } & $* \mathrm{R} 1$ & $* \mathrm{R} 2$ & $* \mathrm{R} 3$ & Mean $\pm \mathrm{SD}$ \\
\hline Lestrimellita sp (diploid males) & 0.460 & 0.465 & 0.465 & $0.463 \pm 0.003$ \\
Lestrimellita sp (females) & 0.455 & 0.465 & 0.470 & $0.463 \pm 0.008$ \\
\hline
\end{tabular}

*R1, *R2 and *R3 : independent replicates. 
breeding, with diploid males as the possible outcome of matched mating. Consequently, since Lestrimellita females mate with a single male (Peters et al., 1999), it may be inferred that sex in Lestrimellita is controlled by a single multiple-allelic locus.

\section{Acknowledgments}

We are grateful to Dr. Lucio Antonio de Oliveira Campos for his assistance and encouragement. This work was supported by the Brazilian agency FAPEMIG (Process numbers: APQ 0858-3.12/07 and APQ 00564-08).

\section{References}

Beye M, Hasselmann M, Fondrk MK, Page RE and Omholt SW (2003) The gene $c s d$ is the primary signal for sexual development in the honeybee and encodes an SR-type protein. Cell 114:419-429.

Barrett SD (2002) Software for scanning microscopy. Proc R Microsc Soc 37:7-14.

Bego LR, Zucchi R and Mateus S (1991) Notas sobre a estratégia alimentar (cleptobiose) de Lestrimelitta limao Smith (Hymenoptera, Apidae, Meliponinae). Naturalia 16:119-127.

Cowan DP and Stahlhut JK (2004) Functionally reproductive diploid and haploid males in an inbreeding hymenopteran with complementary sex determination. Proc Natl Acad Sci USA 101:10374-10379.

de Boer JG, Ode PJ, Vet LEM, Whitfield J and Heimpel GE (2007). Diploid males sire triploid daughters and sons in the parasitoid wasp Cotesia vestalis. Heredity 99:288-294.

Dolezel J and Bartos J (2005) Plant DNA flow cytometry and estimation of nuclear genome size. Ann Bot 95:99-110.

Duchateau MJ and Marien J (1995) Sexual biology of haploid and diploid males in the bumble bee Bombus terrestris. Insectes Soc 42:255-266.

El Agoze M, Drezen JM, Renault S and Periquet G (1994) Analysis of the reproductive potential of diploid males in the wasp Diadromus pulchellus (Hymenoptera, Ichneumonidae). Bull Entomol Res 84:213-218.

Green CL and Oldroyd BP (2002) Queen mating frequency and maternity of males in the stingless bee Trigona carbonaria Smith. Insectes Soc 49:196-202.

Heimpel GE and de Boer JG (2008) Sex determination in the Hymenoptera. Annu Rev Entomol 53:209-230.

Imai HT, Taylor RW, Crosland MWJ and Crozier RH (1988) Modes of spontaneous evolution in ants with reference to the minimum interaction hypothesis. Jpn J Genet 63:159-185.

Krieger MJB, Ross KG, Chang CWY and Keller L (1999) Frequency and origin of triploid in the fire ant Solenopsis invicta. Heredity 82:142-150.

Liebert AE, Sumana A and Starks PT (2005) Diploid males and their triploid offspring in the paper wasp Polistes dominulus. Biol Lett 1:200-203.

Lopes DM, Carvalho CR, Clarindo WR, Praça MM and Tavares MG (2009) Genome size estimation of three stingless bee species (Hymenoptera, Meliponinae) by flow cytometry. Apidologie 40:517-523.

Loureiro J, Rodriguez E, Dolezel J and Santos C (2006) Comparison of four nuclear isolation buffers for plant DNA flow cytometry. Ann Bot 98:679-689.
Marchi P and Melo GAR (2006) Revisão taxonômica das espécies brasileiras de abelhas do gênero Lestrimelitta Friese (Hymenoptera, Apidae, Meliponina). Rev Bras Entomol 50:630 (Abstract in English).

Michener CD (2000) The Bees of the World. Johns Hopkins University Press, Baltimore, $913 \mathrm{pp}$.

Naito T and Susuki H (1991) Sex determination in the sawfly, Athalia rosae ruficornis (Hymenoptera): Occurrence of triploid males. J Hered 82:101-104.

Otto FJ (1990) DAPI staining of fixed cells for high-resolution flow cytometry of nuclear DNA. In: Darzynkiewiez Z, Crissman HA and Robinson JP (eds) Methods in Cell Biology, v. 33. Academic Press, San Diego, pp 105-110.

Peters J, Queller DC, Imperatriz-Fonseca VL, Roubik DW and Strassmann JE (1999) Mate number, kin selection and social conflicts in stingless bees and honeybees. Proc R Soc Lond B 266:379-384.

Plowright RC and Pallet MJ (1979) Worker-male conflict and inbreeding in bumble bees (Hymenoptera, Apidae). Can Entomol 111:289-294.

Rocha MP and Pompolo SG (1998) Karyotypes and heterochromatin variation (C-bands) in Melipona species (Hymenoptera, Apidae, Meliponinae). Genet Mol Biol 21:41-45.

Rocha MP, Pompolo SG and Campos LAO (2003) Citogenética da tribo Meliponini (Hymenoptera, Apidae). In: Melo GAR and Santos IA (eds) Homenagem aos 90 Anos de Jesus Santiago Moure. UNESC, Criciúma, pp 311-320.

Rothenbuhler WC, Kulincevic JM and Kerr WE (1968) Bee genetics. Annu Rev Genet 2:413-438.

Ross KG and Fletcher DJC (1986) Diploid male production - A significant colony mortality factor in the fire ant Solenopsis invicta (Hymenoptera, Formicidae). Behav Ecol Sociobiol 19:283-291.

Sakagami SF (1982) Stingless bees. In: Hermann HR (ed) Social Insects, v. 3. Academic Press, New York, pp 361-423.

Sakagami SF and Laroca S (1963) Additional observations on the habits of the cleptobiotic stingless bees, the genus Lestrimelitta Friese (Hymenoptera, Apoidea). J Fac Sci Hokaido University Ser VI Zool 15:319-339.

Sakagami SF, Roubik DW and Zucchi R (1993) Ethology of the robber stingless bee Lestrimelitta limao (Hymenoptera, Apidae). Sociobiology 21:237-277.

van Wilgenburg E, Driessen G and Beukeboom LW (2006) Single locus complementary sex determination in Hymenoptera: An "unintelligent" design? Front Zool 3:1 (doi:10.1186/1742-9994-3-1).

Whiting PW (1943) Multiple alleles in complementary sex determination of Habrobracon. Genetics 28:365-382.

\section{Internet Resources}

Rasband W (1998) NIH Image is a public domain program developed at the U.S. National Institutes of Health. http://rsb.info.nib.gov/nib-image/ (October 19, 2009).

Image SXM software. http://reg.ssci.liv.ac.uk (October 19, 2009).

\section{Associate Editor: Yatiyo Yonenaga-Yassuda}

License information: This is an open-access article distributed under the terms of the Creative Commons Attribution License, which permits unrestricted use, distribution, and reproduction in any medium, provided the original work is properly cited. 